\title{
Bacterial Causes of Hemorrhagic Gastroenteritis in Dogs and Cats with Detection of Some Virulence and $\beta$ - lactamase Resistance Genes in Escherichia coli and Salmonella by Multiplex PCR
}

\section{Enany, M. E. ${ }^{1}$; Wahdan A. ${ }^{1 ;}$ Marwa El-Metwaly El-Metwaly ${ }^{2}$;} Wafaa M. Hassan3 and Marwa El Sayed Abo Hashem ${ }^{1}$

1. Bacteriology, Immunology and Mycology Department, Faculty of Veterinary Medicine, Suez Canal University, Ismailia, Egypt.

2. Department of Zoonotic Diseases, Veterinary Medicine

Directorate, Damietta.

3.Microbiology, Reference lab. of Quality Control on Poultry

Production, Animal Health Research Institute.

enanyeg@yahoo.com, dr alyw@yahoo.com, mmghobary21@gmail.com, fooaaa@live.com, marwashassan@vet.suez.edu.eg

\begin{abstract}
Hemorrhagic Gastroenteritis (HGE) is a life-threatening disease caused by bacteria or virus or endoparasites or irritant drugs or food allergy. Out of 202 sampled animals, the total bacterial isolates were 104. The identified bacterial isolates were 46 (ะะ. r \%\%) E. coli, 9 (8.65\%) Klebsiella, 5 (₹.80\%) C. perfringens, $22(21.15 \%)$ Proteus spp., 3 ( $\uparrow, \wedge \wedge \%)$ Salmonella spp., 3 (2.88\%) Shigella spp. and $4(3.84 \%)$ Pseudomonas aeruginosa, 4 (3.84\%) Enterobacter species, 2 (1.92\%) Citrobacter species, 2 (1.92\%) Providencia rettgeri, $1(0.96 \%)$ Hafnia species, 1 (0.96\%) Serratia liquefaciens, 1 $(0.96 \%)$ C. bifermentans and $1(0.96 \%)$ C. putrefaciens. EHEC (12/26, 46.15\%), EPEC (9/26, 34.61\%) and ETEC $(4 / 26,15.38 \%)$ strains were detected by E. coli serotyping. Salmonella isolates were serotyped as Salmonella Typhimurium, $S$. Heidelberg and $S$. Infantis. E. coli isolates from dogs were resistant to amoxicillin/clavulanic acid, cephalexin, ceftriaxone, trimethoprim/sulphamethoxazole, tetracycline, and erythromycin. Feline E. coli isolates had moderate resistance to amoxicillin/clavulanic acid, trimethoprim/ sulphonamides, and tetracycline. Salmonella isolates were highly resistant to amoxicillin/clavulanic acid, cephalexin, trimethoprim/sulphamethoxazole, tetracycline, and erythromycin. st 1 and st 2 E. coli virulence genes were detected in $80 \%$ and $60 \%$ of tested E. coli isolates,
\end{abstract}


respectively while $S$. Typhimurium was positive for invA, hilA and fim $\mathrm{H}$ virulence genes and $S$. Heidelberg was positive for inv $\mathrm{A}$ and $f i m \mathrm{H}$ genes. bla $a_{\mathrm{TEM}}$ and $b l a_{\mathrm{CTX}-\mathrm{M} 1} \beta$ lactamase resistance genes were detected in $60 \%$ and $20 \%$ of tested E. coli isolates, respectively. Salmonella Typhimurium was positive for bla $a_{\mathrm{CMY}-1}$ and bla ${ }_{\mathrm{OXA}-2}$ genes, Salmonella Heidelberg was positive for $b l a_{\mathrm{CMY}-1}$ gene. In conclusion, $E$. coli, Salmonella, $C$. perfringens, Klebsiella were major bacterial causes of HGE in dogs and cats. Additionally, $E$. coli and Salmonella isolated from companion animals can carry multidrug resistance genes encoding for extendedspectrum $\beta$-lactamases.

Keywords: Hemorrhagic Gastroenteritis, E. coli, Salmonella, serological identification, antimicrobial sensitivity test, virulence genes, $\beta$-lactamase resistance genes.

\section{Introduction}

Hemorrhagic (HGE) is a disease characterized by sudden vomiting and bloody diarrhea. The symptoms are usually severe, and HGE can be fatal if not treated. The most common bacterial causes of canine enteritis were Escherichia coli (E. coli), Salmonellae, Clostridium perfringens and Campylobacter (Habib et al., 2016). E. coli are Gram-negative rods belonging to the family

Enterobacteriaceae. Domestic animals and pets act as natural reservoir for attaching and effacing $E$. coli (AEEC) strains. AEEC strains include two main groups: enteropathogenic E. coli (EPEC) strains and enterohemorrhagic $E$. coli (EHEC) strains. AEEC strains can cause attaching and effacing
$(\mathrm{A} / \mathrm{E})$ lesions in the gut mucosa of human and animal hosts causing diarrheal disease. Identification of AEEC is performed by screening for the eae gene, their characteristic serotypes and virulence factors (Nataro and Kaper, 1998). EHEC strains produce shiga toxins also carry plasmids coding for enterohemolysin and other virulence functions (Krause et al., 2005). The use of specific toxin genes or molecular typing assays is the best way to differentiate pathogenic $E$. coli from nonpathogenic (Pass et al., 2000). Most cases of Salmonella infection in Dogs are latent and non-clinical and many dogs may be resistant to salmonellosis (Kozak et al., 2003). Salmonellosis isn't a common clinical case in cats although it 
has a reported prevalence in cats by a percentage of $0.36 \%$ to $51.4 \%$ depending on several factors such as population size, housing condition, health status, diet, origin of the cat and method of detection (Paris et al., 2014).

Clostridium perfringens $(C$. perfringens) is an anaerobic, spore-forming Gram-positive bacteria that is found in soil and gastrointestinal tract of vertebrates causing diseases for both humans and animals (Gohari et al., 2015). It has been associated with acute outbreaks of severe diarrhea in human beings, horses, dogs and cats (Songer, 1996).

Companion animals treatment especially dogs with antibacterial drugs such as fluoroquinolones, potentiated sulfonamides, and $\beta$-lactams in bacterial infection, is often performed by veterinary clinicians and it may be occur by non-veterinarians in countries with no strict regulations for using these drugs in animals (Torkan et al., 2015) and prolonged exposure especially in sub-therapeutic doses of antibacterial drugs this caused E. coli carry multidrug resistance genes encoding for extended-spectrum $\beta$-lactamases (Tajbakhsh et al., 2015) additionally causing easy spread of antimicrobial resistance genes among bacteria can be produced by mobile genetic elements as plasmids, and transposons (Randall et al., 2004). The study aimed to detect bacterial causes of HGE in dogs and cats, serological identification, antimicrobial sensitivity test of $E$. coli and Salmonella and detection of some virulence (stx1, stx 2 and eae $\mathrm{A}$ for E. coli, inv $\mathrm{A}$, hilA and fim $\mathrm{H}$ for Salmonella) and $\beta$ lactamase resistance genes in $E$. coli (bla $a_{\text {OХА }}, b_{\text {CTХ-м1 }}$ and bla $\left.a_{\mathrm{TEM}}\right)$ and Salmonella (bla $a_{\mathrm{CMY}}$ 1 , bla $a_{\mathrm{CMY}-2}$ and $\left.b l a_{\mathrm{OXA}-2}\right)$ by multiplex PCR.

\section{Mate rials and methods}

\section{Samples}

A total of 202 rectal swab samples (143 swab samples from dogs and 59 swab samples from cats) were collected from housed dogs and cats suspected to have hemorrhagic gastroenteritis that manifested by bloody diarrhea from Governmental Pet Animals Units and private pet clinics in Damietta and Dakahlia Governorates, Egypt during the period from February 2017 till April 2020, then transferred to laboratory for bacteriological examinations.

\section{Bacteriological examination} Isolation and identification of E. coli, Salmonella and Klebsiella

Fecal swabs were inoculated into buffered peptone water 
(Lab M), incubated at $37^{\circ} \mathrm{C}$ for $24 \mathrm{~h}$, then inoculum was streaked onto the surface of MacConkey's agar (Oxoid) and incubated at $37^{\circ} \mathrm{C}$ for $24 \mathrm{~h}$, for E. coli and Klebsiella. The suspected lactose fermenter colonies were streaked onto eosin methylene blue (EMB) agar plates (Hi-Media). E. coli and Klebsiella isolates were identified by morphological identification on EMB agar, microscopical examination according to Cruickshank et al. (1975) and biochemically according to Kreig and Holt (1984); by indole test, methyl red test, Voges - Proskauer test, citrate utilization test, urease test, triple sugar iron (TSI) test, gelatin hydrolysis test, oxidation-fermentation test, nitrate reduction test, fermentation of sugars. In case of Klebsiella, mucoviscosity was detected according to Shon et al. (2013); where a loopful from the suspected culture was streaked on nutrient agar (Lab M) plates. Positive isolates were designated

as hypermucoviscous K. pneumoniae (HVKP). Negative isolates were designated as classic K. pneumoniae (CKP).

For isolation and identification of Salmonella, samples were pre-enriched in RappaportVassiliadis broth (Lab M) at $41.5^{\circ} \mathrm{C}$ for $24 \mathrm{~h}$ prior to plating on Xylose Lysine Deoxycholate
(XLD) agar (Hi-Media) at $37^{\circ} \mathrm{C}$ for $24 \mathrm{~h}$. Salmonella isolates were identified by morphological identification, microscopical examination according to Cruickshank et al. (1975) and biochemically according to Kreig and Holt (1984).

Isolation and identification of Proteus and Shigella

For isolation and identification of Proteus, samples were preenriched in RappaportVassiliadis broth (Lab M) at $41.5^{\circ} \mathrm{C}$ for $24 \mathrm{~h}$ prior to plating on Xylose Lysine Deoxycholate (XLD) agar (Hi-Media) at $37^{\circ} \mathrm{C}$ for $24 \mathrm{~h}$. Identification was made depending on morphological and biochemical tests according to Kreig and Holt (1984). For isolation and identification of Shigella, samples were enriched in Sodium bi-selenite broth (HiMedia) according to Morris, (1984) at $37^{\circ} \mathrm{C}$ for $24 \mathrm{~h}$ then plating on Xylose Lysine Deoxycholate (XLD) agar (HiMedia) at $37^{\circ} \mathrm{C}$ for $24 \mathrm{~h}$. Also, Streaking on S-S agar (Lab M) for differentiation between Shigella and Salmonella. Identification was made depending on morphological and biochemical tests according to Kreig and Holt (1984).

Isolation and Identification of C. perfringens

For enrichment, samples were inoculated in brain heart 
infusion broth (oxoid) and incubated anaerobically at $37^{\circ} \mathrm{C}$ for $24 \mathrm{~h}$ in an anaerobic jar. Enriched samples were streaked on sulphite polymixin sulphadiazine (SPS) agar plates (Hi-Media) and were incubated anaerobically.

Suspected colonies were stained with Gram's stain and sub cultured on brain heart infusion (BHI) agar plates until they were free from contaminating bacteria. Biochemical identification was made as procedures described by Merchant and Packer (1967); OIE (2000) and Calnek et al. (1997). The pure colonies, suggestive of $C$. perfringens were further streaked on the $5 \%$ sheep blood agar (Hi-Media) and egg yolk agar (Hi-Media) plates and incubated anaerobically for $24 \mathrm{hr}$. The colonies producing characteristic double zone of hemolysis around them on blood agar and producing zone of opalescence around the colonies on egg yolk agar were tentatively identified as $C$. perfringens.

Isolation and Identification of Pseudomonas aeruginosa

Fecal swabs were inoculated into buffered peptone water, incubated at $37^{\circ} \mathrm{C}$ for $24 \mathrm{~h}$, then inoculum was streaked onto the surface of nutrient agar base medium for Pseudomonas (Merck, Oxoid) with cetrimide $(\mathrm{CN})$.

Biochemical identification was made using different biochemical tests such as oxidase test, catalase test, nitrate reduction, indole test, methyl red test, VogesProskauer test, citrate utilization and glucose fermentation test as per Quin et al. (2011) and Carter and Wise (2004).

\section{Serological identification of $E$. coli and Salmonella}

E. coli isolates were serologically identified according to Kok et al. (1996); using rapid diagnostic $E$. coli antisera sets (Set 1: O- antisera and Set 2: H- antisera) (DENKA SEIKEN Co., Japan) for diagnosis of the Enteropathogenic types. Serological identification of Salmonellae was carried out according to Kauffman - White scheme (Kauffman, 1974) for the determination of Somatic $(\mathrm{O})$ and flagellar $(\mathrm{H})$ antigens using Salmonella antiserum (DENKA SEIKEN Co., Japan).

\section{Antimicrobial susceptibility test \\ Some isolates of E. coli and Salmonella were tested against 11 antimicrobial agents (Oxoid) including chloramphenicol $(30 \mu \mathrm{g})$, erythromycin $(15 \mu \mathrm{g})$, trime thoprim/sulfamethoxaz ole $(1.25 / 23.75 \mu \mathrm{g})$, amoxicillin/clavulanic acid $(20 / 10 \mu \mathrm{g})$,}


ciprofloxac in

$(5 \mu \mathrm{g})$, a mpicillin/sulbactam $\quad(10 / 10 \mu \mathrm{g})$, cephalexin $(30 \mu \mathrm{g})$, ceftriaxone $(30 \mu \mathrm{g}), \quad$ cefotaxime $(30 \mu \mathrm{g})$, gentamicin $(10 \mu \mathrm{g}), \quad$ and tetracycline (30 $\mu$ g).

Antimicrobial susceptibility test was performed using disk diffusion method and the results were interpreted according to guidelines of Clinical and Laboratory Standards Institute (2015).

Multiplex PCR for detection of virulence and antibiotic resis tance genes in E. coli and Salmonella

\section{DNA extraction from isolates}

PCR was used for monitoring virulence genes of E. coli (stx 1 , stx2 and eae A) and Salmonella (inv $\mathrm{A}$, hilA and $f i m \mathrm{H})$ and the antibiotic resistance genes of $E$. coli (bla $a_{\text {OХА }}, \quad b l a_{\text {СтХ-М1 }}$ and bla $\left.a_{\mathrm{TEM}}\right)$ and Salmonella (bla $a_{\mathrm{CMY}-}$ $1, \quad b l a_{\mathrm{CMY}-2}$ and bla $\left.a_{\mathrm{OXA}-2}\right)$. Genomic DNA was extracted from five $E$. coli and 3 Salmonella isolates using GeneJET Genomic DNA purification kit Catalog No. K0721 according to the instructions of the manufacturer. The reaction volume was adjusted at $25-\mu 1 \quad(3 \mu \mathrm{l}$ of genomic-DNA, $5 \mu \mathrm{l}$ of $5 \times$ Master Mix, and $20 \mathrm{pmol}$ of each primer, the reaction volume was completed by adding distilled $\mathrm{H}_{2} \mathrm{O}$ ). Positive controls and negative controls (DNA-free) were used in all reactions. The used primers (Pharmacia Biotech) were purchased from (Sigma-Aldrich, Merk Life Science, Via Monte Rosa, Milano, Italy), primers sequences of E. coli and Salmonella virulence genes and $\beta$-lactamase resistance genes were listed in Table 1. PCR cycling conditions for $E$. coli virulence genes (Paton and Paton, 1998) and $\beta$-lactamase resistance genes (Ogutu et al., 2015) were illustrated in Table 2. PCR cycling conditions for Salmonella virulence genes (Singh et al., 2013) and $\beta$ lactamase resistance genes (Hasman et al., 2005) were illustrated in table 2. Finally, the separation of the obtained products was performed using the agar gel electrophoresis (1.5\% agarose stained with ethidium bromide $0.5 \mu \mathrm{g} / \mathrm{ml}$ ), and the gel was photographed. 
Table (1): Primers seque nces, target genes, specific amplicon size of $E$. coli and Salmonella virulence genes and $\beta$-lactamase resistance genes

\begin{tabular}{|c|c|c|c|c|c|}
\hline 苛 & $\begin{array}{c}\text { Target } \\
\text { genes }\end{array}$ & Primer & Oligonucleotide sequence $\left(5^{\prime} \rightarrow 3^{\prime}\right)$ & $\begin{array}{l}\text { Produt } \\
\text { size } \\
\text { (bp) }\end{array}$ & Ref erences \\
\hline \multirow{12}{*}{ ن் } & \multirow{6}{*}{ 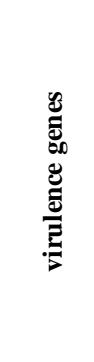 } & stx $1(\mathrm{~F})$ & 5' AT AAATCGCCATTCGTTGACTAC '3 & \multirow{2}{*}{180} & \multirow{6}{*}{$\begin{array}{l}\text { Paton } \\
\text { and } \\
\text { Paton } \\
(1998)\end{array}$} \\
\hline & & stx $1(\mathrm{R})$ & 5' AGAACGCCCACTGAGATCATC '3 & & \\
\hline & & stx2 (F) & 5' GGCACTGTCTGAAACTGCTCC '3 & \multirow{2}{*}{255} & \\
\hline & & stx2 (R) & 5' TCGCCAGTTATCTGACATTCTG '3 & & \\
\hline & & eaeA $(\mathrm{F})$ & 5' GACCCGGCACAAGCATAAGC '3 & \multirow{2}{*}{384} & \\
\hline & & $e a e \mathrm{~A}(\mathrm{R})$ & 5' CCACCTGCAGCAACAAGAGG '3 & & \\
\hline & \multirow{6}{*}{ 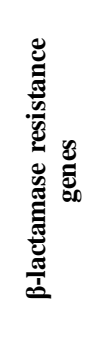 } & $b l a_{\mathrm{OXA}}(\mathrm{F})$ & 5' GGCACCAGATTCAACTTTCAAG '3 & \multirow{2}{*}{564} & \multirow{2}{*}{$\begin{array}{l}\text { Perez et } \\
\text { al. }(2007)\end{array}$} \\
\hline & & $b l a_{\mathrm{OXA}}(\mathrm{R})$ & 5' GACCCCAAGTTTCCTGTAAGTG '3 & & \\
\hline & & $b l a_{\text {СтХ-м1 }}(\mathrm{F})$ & 5' TT AGGAAGTGTGCCGCTGTA '3 & \multirow{2}{*}{655} & \multirow{2}{*}{$\begin{array}{l}\text { Ogutu } \text { et } \\
\text { al. (2015) }\end{array}$} \\
\hline & & $b l a_{\mathrm{CTX-M1}}(\mathrm{R})$ & 5' CGGTTTTATCCCCCACAAC '3 & & \\
\hline & & $b l a_{\mathrm{TEM}}(\mathrm{F})$ & 5' CATTTCCGTGTCGCCCTTATTC '3 & \multirow{2}{*}{800} & \multirow{2}{*}{$\begin{array}{c}\text { Perez et } \\
\text { al. (2007) }\end{array}$} \\
\hline & & $b l a_{\mathrm{TEM}}(\mathrm{R})$ & 5' CGTTCATCCATAGTTGCCTGAC ' $\mathbf{3}$ & & \\
\hline \multirow{12}{*}{ 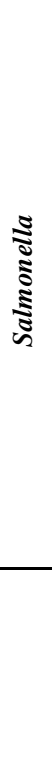 } & \multirow{6}{*}{ 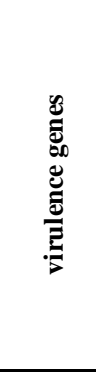 } & $\operatorname{inv} \mathrm{A}(\mathrm{F})$ & 5' GTGAAATTATCGCCACGTTCGGGCA '3 & \multirow{2}{*}{284} & \multirow{2}{*}{$\begin{array}{l}\text { Shanmug } \\
\text { a-samy et } \\
\text { al. (2011) }\end{array}$} \\
\hline & & $\operatorname{inv} \mathrm{A}(\mathrm{R})$ & 5' TCATCGCACCGTCAAAGGAACC '3 & & \\
\hline & & $\operatorname{hil} \mathrm{A}(\mathrm{F})$ & 5' CTGCCGCAGTGTTAAGGATA '3 & 407 & Guo et al. \\
\hline & & $\operatorname{hil} \mathrm{A}(\mathrm{R})$ & 5' CTGTCGCCTTAATCGCATGT '3 & & (2000) \\
\hline & & $\operatorname{fim} \mathrm{H}(\mathrm{F})$ & 5' GGA TCC ATG AAA ATA T ACTC '3 & 1008 & Menghist \\
\hline & & $\operatorname{fim} \mathrm{H}(\mathrm{R})$ & 5' AAG CTT TTA ATC ATA ATC GACTC '3 & & u (2010) \\
\hline & & $b l a_{\mathrm{CMY}-1}(\mathrm{~F})$ & 5' GT GGT GGAT GCCAGCATCC '3 & 0 & \\
\hline & 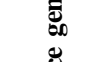 & $b l a_{\mathrm{CMY}-1}(\mathrm{R})$ & 5' GGTCGAGCCGGTCTTGTTGAA '3 & & \\
\hline & స్ & $b^{b l a} a_{\mathrm{CMY}-2}(\mathrm{~F})$ & 5' GCACTT AGCCACCTATACGGCAG '3 & & Hasman \\
\hline & $\stackrel{2}{0}$ & $b^{b l a} a_{\mathrm{CMY}-2}(\mathrm{R})$ & 5' GCTTTTCAAGAATGCGCCAGG '3 & 100 & $(\mathbf{2 0 0 5})$ \\
\hline & Е & $b l a_{\mathrm{OXA}-2}(\mathrm{~F})$ & 5' ACGAT AGTTGTGGCAGACGAAC '3 & & \\
\hline & 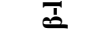 & $b l a_{\mathrm{OXA}-2}(\mathrm{R})$ & 5' ATYCTGTTTGGCGTATCRATATTC '3 & 80 & \\
\hline
\end{tabular}


Table (2): PCR cycling conditions for E. coli and Salmonella virulence genes and $\beta$-lactamase resistance genes

\begin{tabular}{|c|c|c|c|}
\hline Isolates & $\begin{array}{c}\text { PCR } \\
\text { detection } \\
\text { for }\end{array}$ & PCR cycling conditions & References \\
\hline \multirow[t]{2}{*}{ E. coli } & $\begin{array}{c}1- \\
\text { Virulence } \\
\text { genes }\end{array}$ & $\begin{array}{l}\text { 35 PCR cycles, each consisting of: } \\
\text { denaturation at } 95^{\circ} \mathrm{C} \text { for } 1 \mathrm{~min} \text {; } \\
\text { annealing at } 65^{\circ} \mathrm{C} \text { for } 2 \text { min the } \\
\text { first } 10 \text { cycles, } \\
\text { decrementing to } 60^{\circ} \mathrm{C} \text { by cycle } 15 \text {; } \\
\text { elongation at } 72^{\circ} \mathrm{C} \text { for } 1.5 \mathrm{~min} \\
\text { incrementing to } 2.5 \mathrm{~min} \text { from } \\
\text { cycles } 25 \text { to } 35\end{array}$ & $\begin{array}{l}\text { Paton and } \\
\text { Paton } \\
\text { (1998) }\end{array}$ \\
\hline & $\begin{array}{c}2-\beta- \\
\text { lactamase } \\
\text { resistance } \\
\text { genes }\end{array}$ & $\begin{array}{l}\text { initial denaturation at } 94^{\circ} \mathrm{C} \text { for } 10 \\
\text { min; } 30 \text { cycles of denaturation at } \\
94^{\circ} \mathrm{C} \text { for } 30 \mathrm{sec} \text {, } \\
\text { annealing at } 61^{\circ} \mathrm{C} \text { for } 35 \mathrm{sec} \text { and } \\
\text { extension at } 72^{\circ} \mathrm{C} \text { for } 1 \mathrm{~min} \text {; and } \\
\text { final extension at } 72^{\circ} \mathrm{C} \text { for } 9 \text { min }\end{array}$ & $\begin{array}{l}\text { Ogutu } e t \\
\text { al. (2015) }\end{array}$ \\
\hline \multirow{2}{*}{ Salmonella } & $\begin{array}{c}1- \\
\text { Virulence } \\
\text { genes }\end{array}$ & $\begin{array}{l}\text { initial denaturation at } 94^{\circ} \mathrm{C} \text { for } 60 \\
\text { sec, followed by } 35 \mathrm{cycles} \text { of } \\
\text { denaturation at } 94^{\circ} \mathrm{C} \text { for } 60 \mathrm{sec} \text {, } \\
\text { annealing at } 64^{\circ} \mathrm{C} \text { for } 30 \mathrm{sec} \text { and } \\
\text { extension at } 72^{\circ} \mathrm{C} \text { for } 30 \mathrm{sec} \text {, } \\
\text { followed by a final extension at } \\
72^{\circ} \mathrm{C} \text { for } 7 \mathrm{~min}\end{array}$ & $\begin{array}{c}\text { Singh } e t \\
\text { al. }(2013)\end{array}$ \\
\hline & $\begin{array}{l}2-\beta- \\
\text { lactamase } \\
\text { resistance } \\
\text { genes }\end{array}$ & $\begin{array}{l}\text { an initial denaturation step of } 95^{\circ} \mathrm{C} \\
\text { followed by } 35 \text { cycles } \\
\text { denaturation at } 95^{\circ} \mathrm{C} \text { for } 30 \mathrm{sec} \text {, } \\
\text { annealing for } 30 \mathrm{sec} \text { and } \\
\text { elongation for } 1 \mathrm{~min} \text {. at } 72^{\circ} \mathrm{C} \\
\text { a final elongation step at } 72^{\circ} \mathrm{C} \text { for } \\
5 \text { min }\end{array}$ & $\begin{array}{l}\text { Hasman et } \\
\text { al. (2005) }\end{array}$ \\
\hline
\end{tabular}

\section{Results}

Out of the 104 total bacterial isolates, the identified isolates were $46(44.23 \%)$ E. coli, 3 (2.88\%) Salmonella spp., 5 $(4.80 \%) \quad C$. perfringens, 9 $(8.65 \%)$ Klebsiella, $22(21.15 \%)$ Proteus spp., 3 (2.88\%) Shigella spp., 4 (3.84\%) Pseudomonas species, $4(3.84 \%)$ Enterobacter species, $2(1.92 \%)$ Citrobacter species, 2 (1.92\%) Providencia rettgeri, 1 (0.96\%) Hafnia species, 1 (0.96\%) Serratia liquefaciens, 1 (0.96\%) $C$. bifermentanas and $1(0.96 \%) C$. putrefaciens. E. coli was isolated from $28(26.92 \%)$ dogs and $18(17.30 \%)$ cats. Twentysix isolates were subjected to 
serological identification as shown in Table 3, the isolates belonged to $11 \mathrm{O}$-serogroups and were distributed as the following: O159 (2/26, 7.69\%), O6 (4/26, 15.38\%), O45 (2/26, $7.69 \%)$, O91 (6/26, 23.07\%), O2 (1/26, 3.84\%), O128 (3/26, $11.53 \%)$, O26 (3/26, $11.53 \%)$, O55 (1/26, 3.84\%), O127 (1/26, $3.84 \%), \quad 0121 \quad(2 / 26, \quad 7.69 \%)$ and $\mathrm{O} 146(1 / 26,3.84 \%)$. The percentages of isolation of EHEC, EPEC and ETEC strains were $12 / 26 \quad(46.15 \%), \quad 9 / 26$ (34.61\%), and 4/26 (15.38\%), respectively. All serotypes of EHEC strains isolated from both canine and feline cases were non-O157. By antimicrobial susceptibility test, E. coli isolates from dogs were resistant to amoxicillin/clavulanic acid by a percentage of $(66.67 \%)$, cephalexin

ceftriaxone

cefotaxime $(66.67 \%)$, $(66.67 \%)$, trimethoprim/

$(33 \%)$, sulphamethoxazole $\quad(66.67 \%)$, tetracycline $(100 \%)$, and erythromycin $(100 \%)$. Feline $E$. coli isolates had moderate resistance to amoxicillin/clavulanic acid (50\%), trimethoprim/ sulphonamides (50\%), and tetracycline $(50 \%)$. Concerning prevalence of $E$. coli virulence genes by multiplex PCR as shown in Figure 1, stx 1 gene was detected in $80 \%$ of tested $E$. coli isolates, stx2 gene was detected in $60 \%$ of tested $E$. coli isolates, and two isolates carry both stx genes, while all tested $E$. coli isolates were negative for eaeA gene. Concerning antibiotic resistance genes, All $E$. coli isolates were negative for $b l a_{\mathrm{OXA}}$ gene while $b l a_{\mathrm{CTX}} \mathrm{M} 1$ gene was detected in $20 \%$ of tested $E$. coli isolates and bla $a_{\mathrm{TEM}}$ gene was detected in $60 \%$ of tested isolates as shown in Figure 2.

Three Salmonella spp. were isolated from dogs by a percentage of $(2.88 \%)$ from the 104 total bacterial isolates, no Salmonella isolates were detected in cats. The three Salmonella isolates were serotyped as $S$. Typhimurium, $S$. Heidelberg and $S$. Infantis. By antimicrobial susceptibility test, Salmonella isolates were highly resistant to amoxicillin/ clavulanic acid (100\%), trimethoprim/sulphamethoxazol e $(66.67 \%)$, tetracycline $(66.67 \%)$, and erythromycin (66.67\%).

Typhimurium was positive invA, hilA and fimH genes by multiplex PCR, while Salmonella Heidelberg was positive for inv A and $f i m \mathrm{H}$ genes as shown in Figure 3. Concerning antibiotic resistance genes, Salmonella Typhimurium isolate was positive for bla $a_{\mathrm{CMY}-1}$ and bla $a_{\text {OXA-2 }}$ genes, Salmonella Heidelberg was positive for 
bla $_{\mathrm{CMY}-1}$ gene as shown in Figure 4. Results of string test for Klebsiella species identified K. pneumoniae (HVKP) and 3 isolates of classic $K$. pneumoniae (CKP).

4 isolates of hypermucoviscous

Table (3): Serological identification of some E. coli isolates

\begin{tabular}{|c|c|c|}
\hline Serial No. (animal) & Serodiagnosis & Strain characterization \\
\hline 1 (Dog) & O159:H4 & \multirow[t]{2}{*}{ EPEC } \\
\hline 2 (Dog) & O6 & \\
\hline 3 (Dog) & O6:H11 & EHEC \\
\hline 4 (Dog) & $\mathrm{O} 45: \mathrm{H} 2$ & EPEC \\
\hline 5 (Dog) & O91:H21 & EHEC \\
\hline 6 (Dog) & $\mathrm{O} 2: \mathrm{H} 7$ & \multirow{2}{*}{ EPEC } \\
\hline 7 (Dog) & O6 & \\
\hline 8 (Dog) & $\mathrm{O} 128: \mathrm{H} 2$ & ETEC \\
\hline 9 (Dog) & O6 & EPEC \\
\hline 10 (Dog) & O91:H21 & \multirow{4}{*}{ EHEC } \\
\hline 11 (Dog) & O26:H11 & \\
\hline 12 (Dog) & $\mathrm{O} 91: \mathrm{H} 21$ & \\
\hline 13 (Dog) & O91:H21 & \\
\hline 14 (Dog) & O55:H7 & EPEC \\
\hline 15 (Dog) & O26:H11 & \multirow{4}{*}{ EHEC } \\
\hline 16 (Dog) & $\mathrm{O} 91: \mathrm{H} 21$ & \\
\hline 17 (Dog) & O26:H11 & \\
\hline 18 (Cat) & O91:H21 & \\
\hline 19 (Cat) & $\mathrm{O} 45: \mathrm{H} 2$ & EPEC \\
\hline 20 (Cat) & O127:H6 & ETEC \\
\hline 21 (Cat) & O121:H7 & \multirow[t]{2}{*}{ EHEC } \\
\hline 22 (Cat) & O121:H7 & \\
\hline 23 (Cat) & O128:H2 & ETEC \\
\hline 24 (Cat) & O159 & EIEC \\
\hline 25 (Cat) & O128:H2 & ETEC \\
\hline 26 (Cat) & $\mathrm{O} 146: \mathrm{H} 21$ & EPEC \\
\hline
\end{tabular}




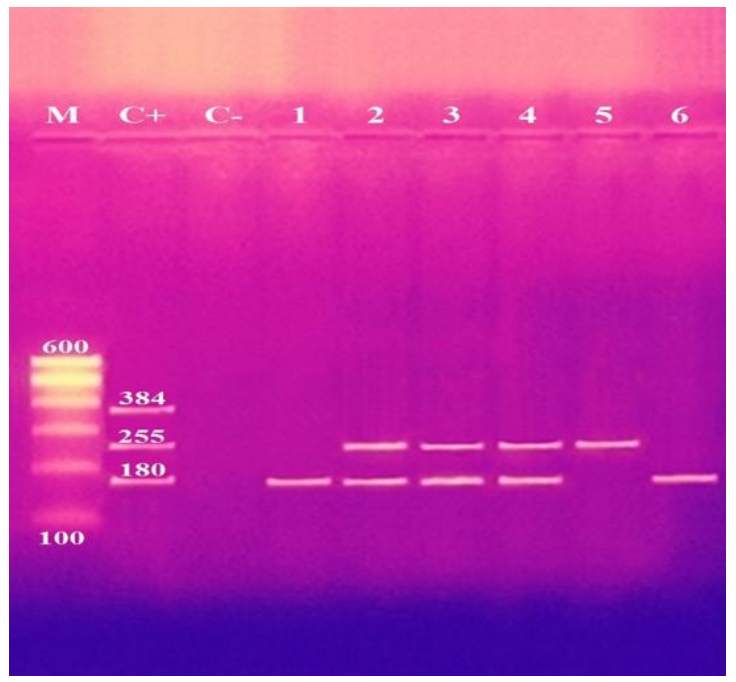

Figure (1): Agarose gel electrophoresis of multiplex PCR of stx 1 (180bp), stx2 (255 bp) and eaeA (384 bp) virulence genes for characterization of Enteropathogenic E. coli. Lane M: 100 bp ladder as molecular size DNA marker. Lane $\mathbf{C}+$ : Control positive $E$. coli for stx 1 , st 2 and eae A genes. Lane C-: Control negative Lanes 1 (O45) \& 6 (0128): Positive E. coli strains for $s t x 1$ gene. Lane 5 (0121) : Positive E. coli strain for $s t x 2$ gene. Lanes 2 (055), 3 \& 4 (091): Positive E. coli strains for stx 1 and stx 2 genes.

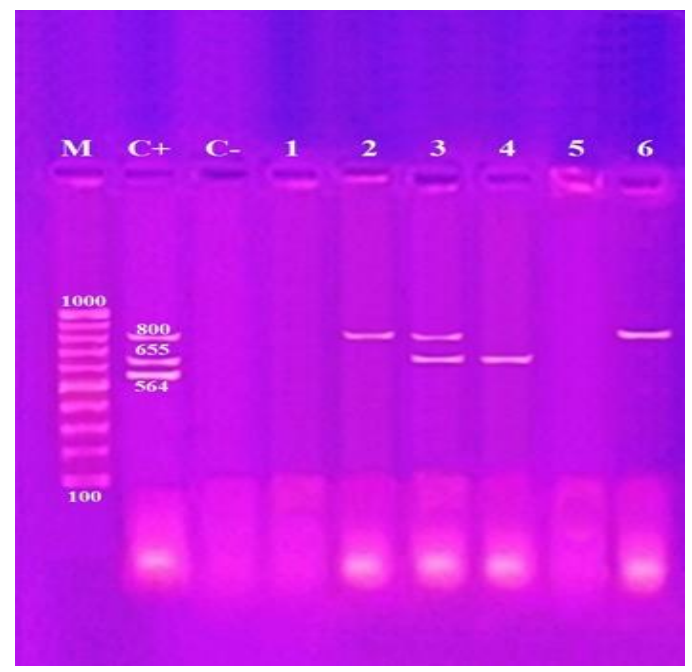

Figure (2): Agarose gel electrophoresis of multiplex PCR of bla $a_{\text {OXA }}$ (564 bp), bla $a_{\mathrm{CTX}-\mathrm{M} 1}(655 \mathrm{bp})$ and bla $a_{\mathrm{TEM}}(800 \mathrm{bp})$ as antibiotic resistance genes of Enteropathogenic E. coli. Lane M: 100 bp ladder 
as molecular size DNA marker. Lane $\mathbf{C}+$ : Control positive for $b l a_{\text {OXА, }} b l a_{\text {CTX-M1 }}$ and $b l a_{\text {TEM }}$ genes. Lane C-: Control negative. Lanes 2 (055) \& 6 (O128): Positive strains for bla $a_{\text {TEM }}$ gene. Lanes 4 (091): Positive strain for bla $a_{\mathrm{CTX}-\mathrm{M} 1}$ gene. Lanes 3 (O91): Positive strains for $b l a_{\mathrm{CTX}-\mathrm{M} 1}$ and $b l a_{T E M}$ genes. Lanes 1 (O45) \& 5 (O121): Negative strains for $l a_{\mathrm{OXA}}, b l a_{\mathrm{CTX}-\mathrm{M} 1}$ and $b l a_{\mathrm{TEM}}$ genes.

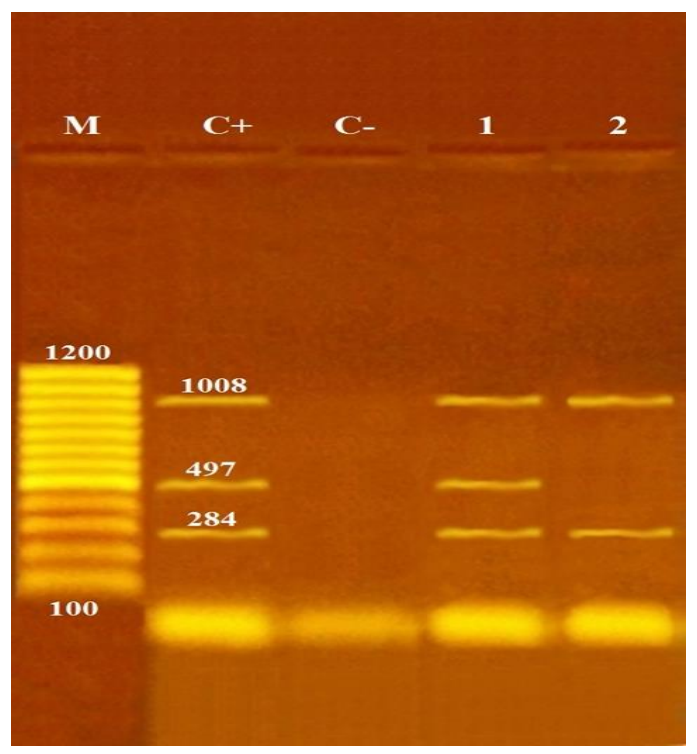

Figure (3): Agarose gel electrophoresis of multiplex PCR of invA (260 bp), hilA (497 bp) and fimH (1008 bp) virulence genes for characterization of Salmonella species. Lane M: 100 bp ladder as molecular size DNA marker. Lane C+: Control positive strain for invA, hilA and fimH genes. Lane C-: Control negative. Lane 1: D24 (S. Typhimurium): Positive Salmonella for invA, hilA and fim $\mathrm{H}$ genes. Lane 2: D35 (S. Heidelberg): Positive Salmonella for invA and fim $\mathrm{H}$ genes. 


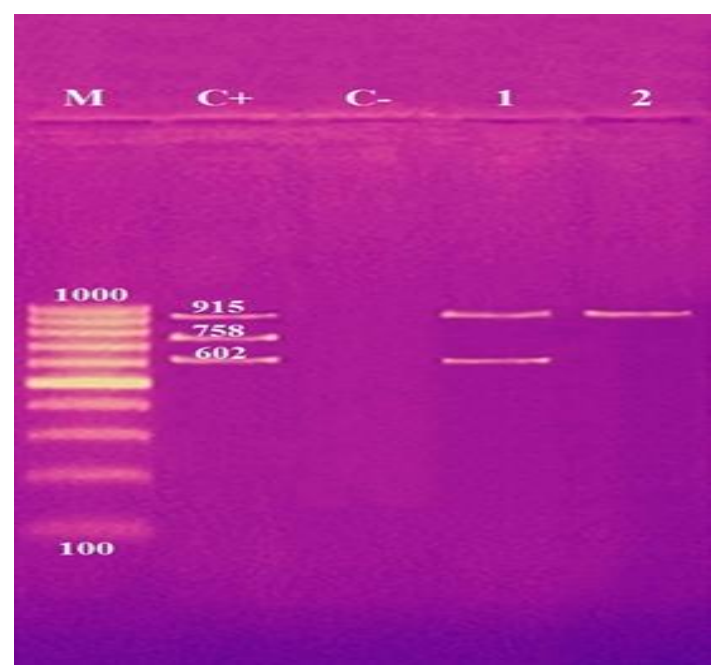

Figure (4): Agarose gel electrophoresis of multiplex PCR for identification of $\beta$-lactamase resistance genes of Salmonella species represented by bla $a_{\mathrm{CMY}-1}(915 \mathrm{bp})$, bla $_{\mathrm{CMY}-2}(758 \mathrm{bp})$ and bla $_{\mathrm{OXA}-2}(602$ bp). Lane M: 100 bp ladder as molecular size DNA marker. Lane 1: Control positive for $b l a_{\mathrm{CMY}-1}, b l a_{\mathrm{CMY}-2}$ and $b l a_{\mathrm{OXA}-2}$ genes. Lane 2: Control negative. Lane 1 ( $S$. Typhimurium): Positive strain for bla $_{\mathrm{CMY}-1}$ and bla $_{\mathrm{OXA}-2}$ genes. Lane 2 (S. Heidelberg): Positive strain for bla CMY-1 gene.

\section{Discussion}

The most common bacterial species isolated from dogs with Acute Hemorrhagic Diarrhea Syndrome (AHDS) was E. coli that is considered an enteropathogen (Marks and Kather, 2003). In the present study $E$. coli was the most prevalent isolate $46(44.23 \%)$. Serologically, enterohemorrhagic $E$. coli (EHEC), enteropathogenic $E$. coli (EPEC) and enterotoxigenic E. coli (ETEC) strains were the most detected strains in the present work, additionally, all serotypes of EHEC strains isolated from both canine and feline cases were non-O157; these results were in agreement with Marks and Kather (2003) who detected the three pathotypes EHEC, ETEC and EPEC in dogs and reported that there is little information demonstrating the $\mathrm{O} 157: \mathrm{H} 7$ role in dogs specifically. By antimicrobial susceptibility test, canine $E$. coli isolates were resistant

to amoxicillin/clavulanic acid, cephalexin, ceftriaxone, trimethoprim/sulphamethoxazol e, tetracycline, and erythromycin while feline $E$. coli isolates had high to moderate resistance to 
cephalexin,

amoxicillin/clavulanic acid, trimethoprim/sulphonamides

and tetracycline. As a result of their resistance for the previous antimicrobial agents, E. coli isolated from dogs and cats in the current study was classified as multidrug resistant (MDR) as mentioned by Magiorakos et al. (2012). The use of PCR has become widely adopted to distinguish pathogenic $E$. coli strains from normal gut flora by detection of virulence genes (Piccoa et al., 2015), additionally, PCR can identify EPEC and differentiate from EHEC (stx1, stx2,eae) where all $E$. coli isolates were confirmed as EPEC based on the presence of the eae gene and were not EHEC (absence of stx 1 and stx2) (Kjaergaard et al., 2016). In the current study, EHEC was commonly detected where stx 1 gene was detected in $80 \%$ of tested E. coli isolates and $s t x 2$ gene was detected in $60 \%$ of tested E. coli isolates. The $b l a_{\mathrm{TEM}}$, and $b l a_{\text {СTX-M }}$ genes are responsible for production of TEM $\beta$-lactamases and CTXM $\beta$-lactamases, large families of enzymes with evolutionary affinity and broad-spectrum resistance to $\beta$-lactam antibiotics (Al-Jassera, 2006). In our analysis, among $E$. coli strains, high levels of resistance to amoxicillin/clavulanic acid by a percentage of $(66.67 \%)$, cephalexin $(66.67 \%)$ and ceftriaxone $(66.67 \%)$ were observed because bla $_{T E M}$ and bla $a_{C T X-M 1}$ antibiotic resistance genes were detected in $60 \%$ and $20 \%$ of tested E. coli isolates, respectively.

In the present study, the prevalence of Salmonella isolates among dogs was $2.88 \%$, this result was in accordance with that reported by (Marks and Kather (2003), who concluded that canine clinical salmonellosis is tremendously rare in domestic pet dogs and isolation percentage ranging from $0 \%$ to $2 \%$ in diarrheic dogs. Also, Ojo and Adetosoye (2009); recorded that the percentage of Salmonella isolates was $3.7 \%$ from diarrhoeic and non-diarrhoeic dogs. However, no Salmonella isolates were detected in cats in the present study, this result came in agreement with that documented by Gallaway et al. (2008) who reported that the clinical form of Salmonella infection in cats is uncommon, and cats can carry Salmonella asymptomatically. In the present study, the three Salmonella isolates were serotyped as Salmonella Typhimurium, $S$. Heidelberg and $S$. Infantis. Seepersadsingh et al. (2004); reported 28 different serovars of Salmonella in dogs while in a study performed by Ojo and 
Adetosoye (2009), all the Salmonella isolates were serotyped as $S$. Typhimurium. Dogs that fed raw chicken may be a source of environmental contamination with Salmonella. Since dogs can acquire Salmonella from their food, especially poultry products, the food should be prepared in a way that will eliminate pathogens from the food (Joffe and Schlesinger, 2002). Dogs that harbour Salmonella can serve as a source of Salmonella infection to their human companions. They can also disseminate the organism by contaminating the environment thereby exposing the general public and other animals to the risk of infection (Ojo and Adetosoye, 2009). In the curre nt study, the antibiotic sensitivity pattern of Salmonella isolates revealed that Salmonella isolates were highly resistant to amoxicillin/clavulanic acid (100\%), cephalexin (100\%), trimethoprim/sulphamethoxazol

e $(66.67 \%)$, tetracycline $(66.67 \%)$, and erythromycin $(66.67 \%)$. This result was near to that reported by Ojo and Adetosoye (2009) where they recorded $100 \%$ resistance to erythromycin and Cloxacillin, resistance to tetracycline (70.6\%), ampicillin (47.1\%), cefuroxime (52.9\%), amoxicillin (35.3\%), cotrimoxazole $(76.5 \%)$ and gentamicin (35.3\%). The multiple antibiotic resistance pattern among the Salmonella isolates attributed to indiscriminate use of antibiotics in animals could be responsible for emergence of resistant strains of bacteria so the use of antibiotics should therefore be well regulated and instituted only when it is absolutely indicated (Ojo and Adetosoye, 2009). In the present study, Salmonella Typhimurium was positive for the three genes; $i n v \mathrm{~A}$, hilA and $f i m \mathrm{H}$ genes, while Salmonella Heidelberg was positive for invA and $\operatorname{fim} \mathrm{H}$ genes, these results were similar to that detected by Salih and Yousif (2018) who found that all Salmonella isolates carried invA. The previous genes considered factors of virulence as the invA gene is related to host recognition and internalization of the bacterium during invasion of epithelial cells, hilA gene is related to the cell recognition and invasion process (Borges et al., 2013) and fim $\mathrm{H}$ gene has an important role in adhesion of bacteria during the colonization process and host tissue invasion (Kuźmińska-Bajor et al., 2015). Concerning Salmonella $\beta$ lactamase resistance genes in the current work, $S$. Typhimurium was positive for bla $_{\mathrm{CMY}-1}$ and bla $a_{\mathrm{OXA}-2}$ genes. $S$. Heidelberg was positive for 
bla $_{\mathrm{CMY}-1}$ gene. In the present work, Salmonella showed high levels of resistance to amoxicillin/clavulanic acid (100\%) and cephalexin (100\%), because $b l a_{\mathrm{CMY}-1}$ and $b l a_{\mathrm{OXA}-2}$ antibiotic resistance genes were detected in tested Salmonella isolates; this result was in accordance with Winokur et al. (2000) and Mulvey et al. (2003) who found that $b l a_{\mathrm{CMY}}$ and $b l a_{\text {OXA }}$ genes have been found to encode ESBL resistance in Salmonella.

\section{Conclusion}

It may be concluded from this study that bacterial causes of hemorrhagic gastroenteritis in dogs and cats were E. coli, Salmonella, C. perfringens, and Klebsiella. E. coli and Salmonella isolates tested by antimicrobial susceptibility test were resistant to $\beta$-lactams as $E$. coli isolates had bla $a_{\mathrm{TEM}}$ and $b_{\text {CT X-M1 } 1} \beta$-lactamase resistance genes and Salmonella had $b l a_{\mathrm{CMY}-1}$ and $b l a_{\mathrm{OXA}-2} \beta-$ lactamase resistance gene. Hence, it is recommended the proper use of antimicrobial agents in the veterinary sector.

\section{Author contributions}

MEE and ME designed the study. MEE, AW and MEA collected the samples, and applied bacteriological examinations. MEE, MEA and AW performed serological identification. MEA and MEE wrote the manuscript. ME, MEE, AW, MEA and WEH applied PCR testing. All authors have read and approved the final manuscript.

\section{References}

Al-Jassera, A. M. (2006): Extended-spectrum betalactamases (ESBLs): a global problem, Kuwait Medical Journal; 38: 171-185.

Borges, K.A., Furian, T.Q., Borsoi, A., Moraes, H.L., Salle, C.T., Nascimento, V.P. (2013): Detection of virulenceassociated genes in Salmonella Enteritidis isolates from chicken in South of Brazil. Pesq Vet Bras.; 33:1416-1422.

Calnek, B.W., Bames, H.J., Beard, C.W., McDougald, L.R., Saif, Y.M. (1997): Disease of Poultry, 10th edition, lowa State University Press, Ames, lowa, USA.

Carter, G.R. and Wise, D.J. (2004): Essentials of Veterinary Bacteriology and Mycology. 6th ed. The Iowa State Press, Iowa, p125-126.

\section{Clinical and Laboratory} Standards Institute (2015): Performance Standards for Antimicrobial Susceptibility Testing; $\quad$ Twenty-Fifth Informational Supplement. Vol. 35. Clinical and Laboratory Standards Institute, Wayne, PA, USA. 
Cruickshank, R.; Duguid, J.; Marmion, B. and Swain, R.H. (1975): Medical Microbiology. 12th Ed., Edinburg, London and New York.

Gallaway T., Edrington T., Anderson R., Byd J. and Nibest D. (2008): Gastrointestinal microbial ecology and the safety of our food supply as related to Salmonella. J. Anim. Sci.; 86: E 163- E 172.

Gohari M. I., Parreira R.V., Nowell J.V., Nicholson M.V., Oliphant K. and Prescott F.J. (2015): A Novel Pore-Forming Toxin in Type A Clostridium Perfringens Is Associated with Both Fatal Canine Hemorrhagic Gastroenteritis and Fatal Foal Necrotizing Enterocolitis, Department of Pathology, University of Guelph, Guelph, Ontario, Canada.

Guo X., Chen J., Beuchat, L. and Brackett, R. (2000): PCR detection of Salmonella enterica serotype Montevideo in and on raw tomatoes using primers derived from hilA. Appl. Environ. Microbiol., 66: 52485252.

Habib I., Anjum A.A., Rabbani M., Ahmad D.UM., Ali A.M., M. Nawaz M., Kamran M. and Khan M.H. (2016): Occurrence of Antimicrobial Resistant Bacteria in Dogs Suffering from
Enteritis, The Journal of Animal \& Plant Sciences, 26(1), Page: 13-16, ISSN: 1018-7081.

Hasman, H.; Mevius, D.; Velman, K.; Olesen, I. and Aarestrup, F. (2005): $\beta$ lactamase among extendedspectrum $\beta$-lactamase (ESBL)resistant Salmonella from poultry, poultry products and human patients in the Netherlands. J. Antimicrobial. Chemotherapy; 56: 115-121.

Joffe, D. J. and Schlesinger, D. P. (2002): Preliminary assessment of the risk of Salmonella infection in dogs fed raw chicken diets. Can. Vet. J.; 43: 441-442.

Kauffiman, G. (1974): Kauffmann white scheme. J. Acta. Path. Microbiol. Sci., 61:385.

K.jae rgaard, A.B., Carr, A.P. and Gaunt, M.C. (2016): Enteropathogenic Escherichia coli (EPEC) infection in association with acute gastroenteritis in 7 dogs from Saskatchewan. Can Vet J; 57:964-968.

Kok, T.; Worswich, D. and Gowans, E. (1996): Some serological techniques for microbial and viral infections. In Practical Medical Microbiology (Collee, J.; Fraser, A.; Marmion, B. and Simmons, A., eds.), 14th ed., 
Edinburgh,

Livingstone, UK.

Kozak M., Horosova K., Lasanda V., Bilek J., Kyselova J. (2003): Do dogs and cats present a risk of transmission of salmonellosis to human? Bratisl. Lek. Listy. 104, 323-328.

Krause G., Zimmermann S. and Beutin L. (2005): Investigation of domestic animals and pets as a reservoir for intimin- (eae) gene positive Escherichia coli types. Veterinary Microbiology; 106: p.87-95.

Kreig, N. and Holt, J. (1984): Bergey's Manual of systemic bacteriology, Vol.1.William and Wilkins, Baltimore, M.D.21202, USA.

Kuźmińs ka-Bajor

M, Grzymajło K, Ugorski $M$. (2015): Type 1 fimbriae are important factors limiting the dissemination and colonization of mice by Salmonella Enteritidis and contribute to the induction of intestinal inflammation during Salmonella invasion. Front Microbiol; 6:276.

Magiorakos, A.P., Srinivasan, A., Carey R. B. et al. (2012): Multi drug resistant, extensively drug-resistant and pandrugresistant bacteria: an international expert proposal for interim standard definitions for acquired resistance," Clinical
Microbiology and Infection; 18: 268-281.

Marks S.L. and Kather E.J. (2003): Bacterial associated diarrhea in the dog: a critical appraisal. Vet Clin North Am Small Anim Pract; 33: 10291060.

Menghistu, H. (2010): Studies on molecular heterogeneity among Salmonella Gallinarum isolates of poultry origin. M.V.Sc. Thesis, Deemed Univ., IVRI, Izatnagar, Bareilly.

Merchant, I.A. and Packer, R.A. (1967): Veterinary Bacteriology and Virology. Seventh edi. The Iowa University Press, Ames, Iowa, USA, pp. 286-306.

Morris, G.K. (1984): Shigella. In: Compendium of Methods for the Microbiological Examination of Foods, 2nd edition. APHA, Washington DC. pp. 343-350.

Mulvey, M.R., Soule, G., Boyd, D. et al. (2003): Characterization of the first extended spectrum $\beta$-lactamase producing Salmonella isolate identified in Canada. J Clin Microbiol; 41: 460-462.

Nataro, J. P., and J. B. Kaper (1998): Diarrheagenic Escherichia coli. Clin. Microbiol. Rev.; 11:142-201.

OIE (Office International Des Epizooties) (2000): Mannual of 
standards for diagnostics test and vaccines. OIE Guide-2.

Ogutu, J.; Zhang, Q.; Huang, Y.; Yan, H.; Su, L.; Gao, B.; Zhang, W.; Zhao, J. Cai, W.; Li, W.; Hong Zhao, H.; Chen, Y.; Song, W.; Chen, X.; Fu, Y. and Zhang, F. (2015): Development of a multiplex PCR system and its application in detection of blaSHV, blaTEM, blaCTX-M1, blaCTX$M-9$ and blaOXA-1 group genes in clinical Klebsiella pneumoniae and Escherichia coli strains. The Journal of Antibiotics; 68: 725-733.

Ojo E. O. and Adetosoye I. A. (2009): "Salmonella Typhimurium infection in diarrhoeic and non-diarrhoiec dogs in Ibadan, Nigeria," Veterinarski Arhiv, vol. 79(4): 371-377.

Paris J.K., Wills S., Balzer H.J., Shaw D.J., Gunn-Moore D.A. (2014): Enteropathogen co-infection in UK cats with diarrhea. BMC Vet Res; 10:111.

Pass M.A., Odedra R., Batt R.M. (2000): Multiplex PCRs for identification of $E$. coli virulence genes. $\mathrm{J}$ Clin Microbiol, 38: 2001-2004.

Paton, J.C. and Paton, A. W. (1998): Pathogenesis and diagnosis of Shiga- toxinproducing Escherichia coli infections. Clin. Microbiol. Rev.; 11(3):450-479.

Perez, F.; Jones, H.; Hanson, N. and Geyer, C. (2007): Global challenge of multidrugresistant Acinetobacter baumannii. Antimicrob. Agents, Chemother.; 51: 3471-3484.

Piccoa, Y.N., Alustizaa, F.E., Bellingeria, R.V., Grossoa, M.C., Mottab, C.E., Larriestrab, A.J., Vissiob, C., Tirantib, K.I, Terzoloc, H.R., Moreirac, A.R. and Vivasa, A.B. (2015): Molecular screening of pathogenic Escherichia coli strains isolated from dairy neonatal calves in Cordoba province, Argentina. Rev Argent Microbiol; 47:95102.

Quinn, P.J., Markey, B.K., Leonard, F.C., Fitz Patrick, E.S., Fanning, S. and Hartigan, P.J. (2011): Veterinary Microbiology and Microbial Diseases. 2nd ed. Blackwell Publishing Ltd., Ames, IA., p287-290.

Randall L.P., Cooles W.S., Osborn K.M., Piddock J.L., Woodward J.M. (2004): Antibiotic resistance genes, integrons and multiple antibiotic resistance in thirty-five serotypes of Salmonella enterica isolated from humans and animals in the UK. J Antimicrob Chemother; 53:208-216. 
Salih W. and Yousif A.A. (2018): Molecular detection of Salmonella Typhimurium isolated from canine feces by PCR, Advances in Animal and Veterinary Sciences; 6:542-547.

Seepersadsingh, N., Adesiyun, A. A. and Seebaransingh, $R$. (2004): Prevalence and antimicrobial resistance of Salmonella spp. in nondiarrhoiec dogs in Trinidad. J. Vet. Med. B. Infect. Dis; 51: 337-342.

Shanmugas amy, M. Velayutham, T. and Rajeswar, J. (2011): InvA gene specific PCR for detection of Salmonella from broilers. Vet. World; 4(12): 562-564.

Shon, A.; Bajwa, R. and Russo, T. (2013): Hypervirulent (hypermucoviscous) Klebsiella pneumonia: A new and dangerous breed. Virulence; 4(2): 107-118.

Singh, S., Singh, H., Tewari, S., Prejit, N. and Agarwal R. (2013): Characterization of virulence factors among diverse Salmonella serotypes and sources. Adv. Anim. Vet. Sci.; 1(2): 69-74.

Songer J.G. (1996): Clostridial enteric diseases of domestic animals. Clin Microbiol Rev; 9:216-234.

Tajbakhsh E., Khamesipour F., Ranbar R., Ugwu C.I. (2015): Prevalence of class 1 and class 2 integrons in multidrug resistant Escherichia coli isolated from aquaculture water in Chaharmahal $\mathrm{Va}$ Bakhtiari province, Iran. Ann Clin Microbiol Antimicrob; 14, 37.

Torkan S., Khamesipour F., Anyanwu U.M. (2015):

Detection of virulence and antibacterial resistance genes in Salmonella isolates from diarrhoeic dogs in Iran. Revue Méd Vét; 166:221-228.

Winokur, P.L., B rueggemann, A., DeSalvo, D.L. et al. (2000): Animal and human multidrugresistant, cephalosporinresistant Salmonella isolates expressing a plasmid-mediated CMY-2 AmpC b-lactamase. Antimicrob Agents Chemother.; 44: 2777-2783. 


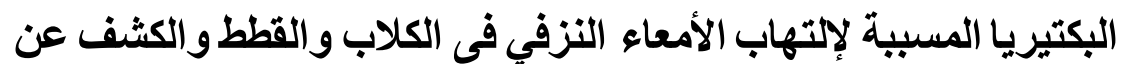

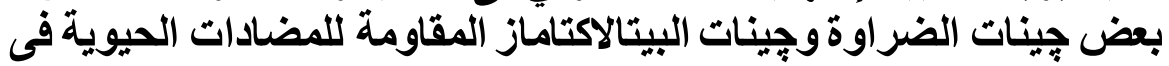
ايشيريشياكولاى والسلمونيلا باستخدام تفاعل البلمرة المتسلسل

\section{محمد السيد عنانى '، على وهدان ، مروه المتولى المتولى '، وفاء محمد حسن 'ب، مروة

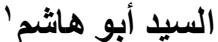

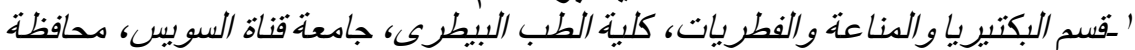

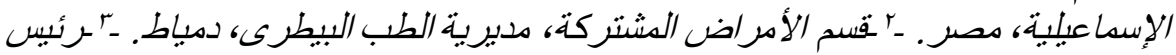

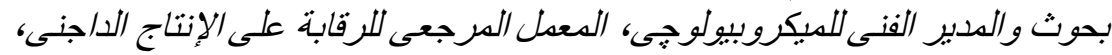
معدل بحوث صحتة الحبيوان.

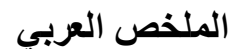

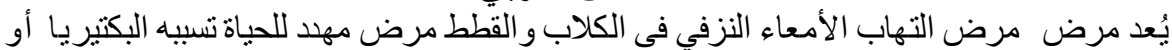

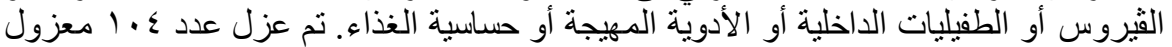

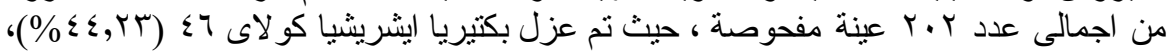

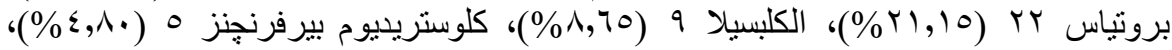

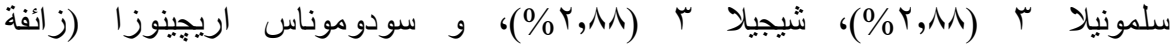

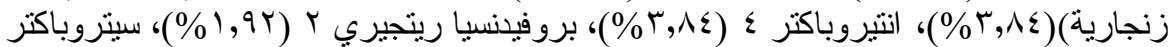

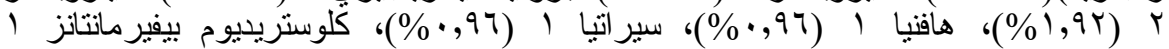

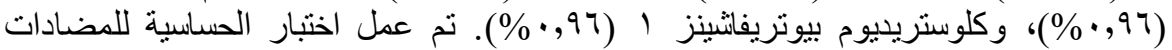

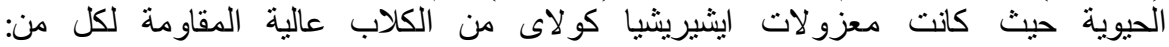

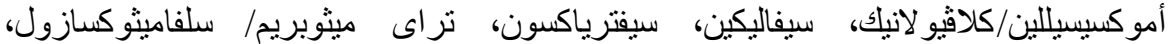

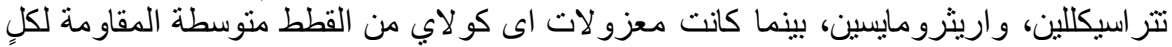

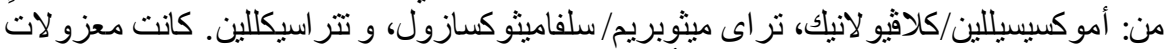

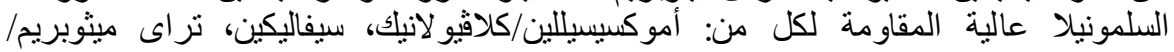

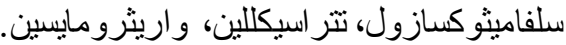

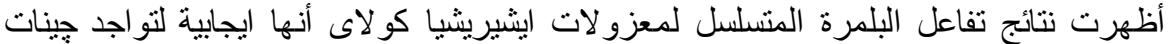
الضراوة stx1

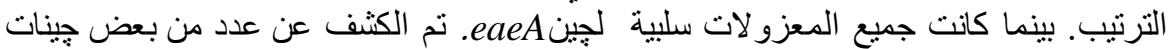

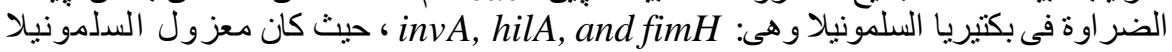

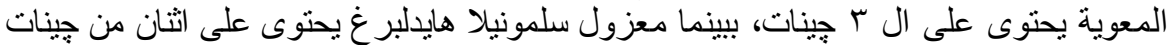

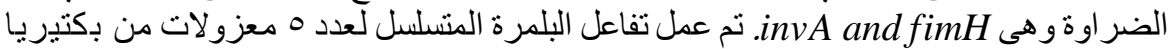
ايثيريثيا كو لاى لعدد من جينات المقاومة blaCTX - ، blaTEM حيث كانت إيجابية لجين blaOXA, blaCTX-M1, and blaTEM

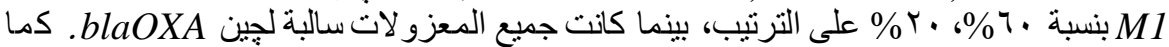

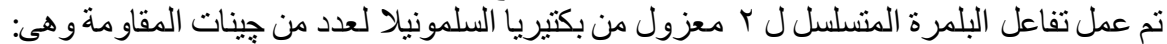
blaCMY-1 blaCMY-2 and blaOXA-2

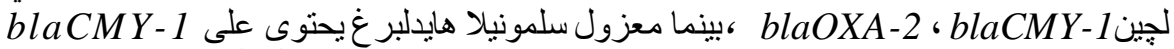

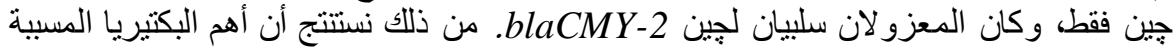

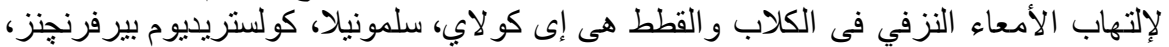

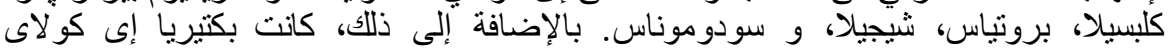

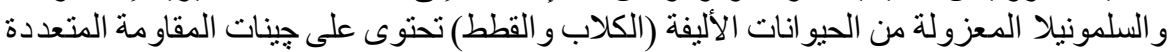

